\title{
PENGEMBANGAN MEDIA PEMBELAJARAN DENGAN BRANCHING PROGRAM BERBASIS KOMPUTER
}

\author{
Witri Ramadhani ${ }^{1)}$, Joni Andre ${ }^{2)}$ \\ ${ }^{1}$ Prodi Pendidikan Teknik Elektronika, Universitas Muhammadiyah Riau \\ ${ }^{2}$ Prodi Pendidikan Teknologi dan Kejuruan, Universitas Negeri Padang \\ E-mail : ${ }^{1}$ witrirahmadhani@umri.ac.id, ${ }^{2}$ jhoniandtr@mail.com
}

\begin{abstract}
The purpose of this study is to evaluate whether learning media with a computer-based branching program can improve learning outcome on Digital System Design course or not. IDI (Instruksional Development Institute) Reseacrh and Development $(R \& D)$ has been applied to develop program and to evaluate the effectiveness of learning media with a computer-based program branching on Digital System Design course. There are three stages in this research, defining, developing, and evaluating. Content validity of learning media with a computer-based program branching was found highly valid. Based on the learning outcomes, the effectiveness of learning media was found effective. More over, based on the teachers and the students response, itwas found that the learning media was found very highly practical. Based on the data analysis, it was found that learning media with a computer-based branchingprogram can improve the students' learning outcome on Digital System Design course.
\end{abstract}

Keywords : Learning Media with Computer-Based Branching Program Macromedia Flash 8, IDI (Instructional Development Institute)

\section{INTISARI}

Tujuan dari penelitian ini adalah untuk menguji apakah media pembelajaran dengan branching program berbasis komputer dapat meningkatkan hasil belajar Pembelajaran Perancangan Sistem Digital lebih baik lagi. Model IDI (Instruksional Development Institute) pada Reseacrh and Development (R\&D) telah diaplikasikan untuk mengembangkan program dan menguji efektivitas media pembelajaran dengan branching program berbasis komputer dalam mata kuliah Perancangan Sistem Digital. Tahapannya terdiri dari define, develop, dan evaluate. Pengujian validitas dari media pembelajaran dengan branching program berbasis komputer menunjukkan bahwa media pembelajaran tersebut adalah valid. Berdasarkan hasil belajar mahasiswa, efektifitas media pembelajaran menunjukkan bahwa media pembelajaran ini efektif. Berdasarkan respon dosen dan mahasiswa, itu menunjukkan praktikalitas media pembelajaran ini praktis dengan kategori sangat praktis. Berdasarkan analisis data, media pembelajaran dengan branching program berbasis komputer meningkatkan pembelajaran mahasiswa pada mata kuliah Perancangan Sistem Digital secara signifikan lebih baik lagi.

Kata Kunci : Media Pembelajaran, Branching Program Berbasis Komputer, Macromedia Flash 8, IDI (Instructional Development Institute).

\section{PENDAHULUAN}

Pendidikan secara umum mempunyai arti suatu proses kehidupan dalam mengembangkan diri tiap individu untuk dapat hidup dan melangsungkan kehidupan. Pendidikan di Indonesia secara umum terbagi menjadi beberapa bagian, yaitu pendidikan formal, pendidikan informal dan pendidikan non formal.
Pendidikan formal adalah jalur pendidikan yang terstruktur dan berjenjang yang terdiri atas pendidikan dasar, pendidikan menengah dan pendidikan tinggi. Pendidikan tinggi merupakan jenjang pendidikan setelah pendidikan menengah yang mencakup program pendidikan diploma, sarjana, magister, spesialis, dan doktor yang diselenggarakan oleh perguruan tinggi. 
Salah satu perguruan tinggi di Indonesia yang memiliki peran sebagai lembaga ilmiah dan pusat pembelajaran yaitu Universitas Negeri Padang (UNP) yang terdiri dari beberapa Fakultas diantaranya Fakultas Teknik (FT) yang terdapat Jurusan Teknik Elektronika dengan Program Studi Pendidikan Teknik Elekrtronika (S1), Program Studi Pendidikan Teknik Informatika \& Komputer (S1) dan Program Studi Teknik Elektronika (D3).

Peran yang telah dirumuskan dan direncanakan khususnya oleh Program Studi Teknik Elektronika (D3) dalam (Learning Outcomes) capaian pembelajaran mata kuliah Perancangan Sistem Digital terkait Kerangka Kualifikasi Nasional Indonesia (KKNI) disesuaikan dengan tujuan pendidikan. Agar tujuan pendidikan dapat tercapai, mahasiswa dikondisikan agar mampu berinteraksi dengan lingkungan belajar yang diciptakan oleh dosen, diaplikasikan kedalam proses pembelajaran yang didalamnya mencakup kurikulum, tujuan, isi, bahan ajar, strategi mengajar, media pembelajaran, dan evaluasi.

Proses komunikasi dikatakan efektif ketika terjadi suatu respon terhadap pesan yang disampaikan. Ketika komunikan memahami pesan yang disampaikan, responsnya akan sesuai dengan tujuan dan harapan komunikator. Salah satu unsur yang berpengaruh dalam proses komunikasi adalah media pembelajaran yang digunakan. Komunikasi pada proses pembelajaran berupa pesan yang disampaikan oleh dosen kepada mahasiswa yaitu berupa media pembelajaran. Media pembelajaran adalah komponen penyampaian dapat dimuati pesan yang akan disampikan untuk komunikasi dengan peserta didik, media bisa seperti komputer, proyektor dan lainnya [3].

Kerangka Kualifikasi Nasional Indonesia yang selanjutnya disingkat KKNI adalah kerangka penjenjangan kualifikasi kompetensi yang dapat menyandingkan, menyetarakan dan mengintegrasi kan antara bidang pendidikan dan bidang pelatihan kerja serta pengalaman kerja dalam rangka pemberian pengakuan kompetensi sesuai dengan struktur pekerjaan di berbagai sector.

Mata kuliah Perancangan Sistem Digital Program Studi Teknik Elektronika (D3) merupakan mata kuliah teori dengan kompetensi utama tentang membimbing mahasiswa dalam perancangan proyek akhir yang memerlukan pemahaman dan keterampilan yang baik terhadap konsep gerbang logika, register, rangkaian aritmatika, perancangan logika urutan dalam bentuk sinkron dan perancangan logika urutan dalam bentuk tak sinkron.
Mata kuliah Perancangan Sistem Digital membutuhkan media pembelajaran yang mampu memberikan stimulus dan respon kepada mahasiswa karena sifat mata kuliah ini memahaman dan penerapan, salah satu cara yang dapat ditempuh oleh dosen yaitu dengan memberi visualisasi terhadap materi yang dianggap membutuhkan penjelasan lebih dari sekedar katakata saja. Hal ini sangat diperlukan agar mahasiswa tidak hanya membayangkan apa yang dijelaskan oleh dosen, namun dapat merasakan sendiri pengalaman belajar yang lebih nyata dan maksimal.

Pada abad perkembangan teknologi saai ini khususnya dalam dunia komputer, komputer tidak hanya mampu untuk mengolah angka atau kata saja. Komputer bisa dikatakan sebagai sumber belajar yang menyediakan berbagai macam bentuk media yang memungkinkan peserta didik membuat desain dan konsep dan ilmu pengetahuan, tidak hanya sebagai sarana komputasi dan pengolah kata saja.

Perkembangan teknologi ini membuat ketertarikan mahasiswa pun berubah. Mahasiswa lebih menyukai hal-hal bersifat digital dibandingkan dengan yang sifatnya teks. Siswa cenderung menyukai komputer, gambar, animasi, video, dan terakhir barulah dokumen berbentuk teks. Dalam rangka memaksimalkan pemanfaatannya untuk pembelajaran, komputer dapat digunakan untuk membuat berbagai media pembelajaran yang menarik perhatian mahasiswa untuk belajar.

Kegiatan observasi awal yang dilakukan pada tanggal 2 Februari 2016 terhadap proses pembelajaran di Program Studi Teknik Elektronika (D3) pada mata kuliah Perancangan Sistem Digital, diperoleh informasi bahwa media pembelajaran yang digunakan oleh dosen perlu dikembangkan karena terlihat dari media pembelajaran presentasi sederhana yang digunakan dosen seperti papan tulis dan presentasi powerpoint sehingga tidak menimbulkan ketertarikan, kreatif dan kemandirian dari peserta didik dalam mengikuti proses pembelajaran.

Kegiatan feed back di dalam kelas belum terjadi secara optimal, ini terlihat dari cara mahasiswa menanggapi pembelajaran dari dosen dengan sibuk sendiri dengan kegiatan masingmasing. Proses pembelajaran selama ini tidak melihat gaya belajar siswa yang unik dan tidak mengkondisikan kegiatan remedial dan pengayaan, hal ini terlihat dari cara mahasiswa belajar yang terjadi ketika saat mendekati ujian saja akibatnya mutu materi dan proses pembelajaran tidak sesuai dengan yang diharapkan. Selain itu, peneliti juga memperoleh informasi bahwa sebagian besar hasil belajar mahasiswa berada dibawah standar 
kurikulum Kerangka Kualifikasi Nasional Indonesia (KKNI) yang telah diterapkan. Hal ini terlihat pada hasil belajar mahasiswa yang mengambil mata kuliah Perancangan Sistem Digital yang tercantum pada Tabel 1 .

Tabel 1. Persentase Hasil Belajar Perancangan Sistem Digital Mahasiswa Program Studi Teknik Elektronika

(D3) Semester Januari-Juni 2015

\begin{tabular}{ccccc} 
& Kode & & : ELA285 & \\
\cline { 2 - 5 } No & Seksi & & & \\
\cline { 2 - 5 } & Interval & Interval & Frekuensi \\
& Nilai & Nilai & $\begin{array}{c}\text { Persentase } \\
\text { (f) }\end{array}$ \\
& Angka & Huruf & & \\
\hline $\mathbf{1}$ & $0-39$ & E & 10 & 25,56 \\
$\mathbf{2}$ & $40-49$ & D & 7 & 17,94 \\
$\mathbf{3}$ & $50-54$ & C- & 8 & 20,51 \\
$\mathbf{4}$ & $55-69$ & C & 4 & 10,27 \\
$\mathbf{5}$ & $60-64$ & C + & 6 & 15,38 \\
$\mathbf{6}$ & $65-69$ & B- & 3 & 7,69 \\
$\mathbf{7}$ & $70-74$ & B & 1 & 2,56 \\
$\mathbf{8}$ & $75-79$ & B + & 0 & 0,00 \\
$\mathbf{9}$ & $80-84$ & A- & 0 & 0,00 \\
$\mathbf{1 0}$ & $85-100$ & A & 0 & 0,00 \\
\hline \multicolumn{7}{c}{ Jumlah } & & 39 & 100,00 \\
\hline
\end{tabular}

Tabel 1 mengindikasikan hasil belajar mahasiswa didapatkan masih belum optimal menyesuaikan penilaian dari Standar KKNI yang digunakan oleh Universitas Negeri Padang bahwa nilai yang boleh diperbaiki adalah nilai $\mathrm{E}, \mathrm{D}$ dan C-. Hasil pembelajaran yang rendah disebabkan oleh kurangnya kesiapan mahasiswa menerima materi pembelajaran, media pembelajaran yang kurang efektif serta respon yang diberikan terhadap materi ajar kurang tepat hal ini pada akhirnya berpengaruh kurang baik terhadap hasil belajar mahasiswa.

Media pembelajaran yang bersifat interaktif sangat diperlukan saat proses pembelajaran Perancangan Sistem Digital karena tidak semua materi pembelajaran ini dapat dipahami dengan hanya membaca namun memerlukan media dalam menampilkan yang bersifat abstrak yang sulit dipahami oleh mahasiswa. Salah satu model pembelajaran yang dapat mengatasi permasalahan diatas dapat digunakan pembelajaran tuntuas/mastery learning yang dilakukan dengan menggunakan pembelajaran terprogram. Ada dua jenis pembelajaran yaitu program dengan konsep linear dan program dengan konsep bercabang [4]. Pembelajaran terprogram menghadirkan instruksi pembelajaran dalam urutan logis dan banyak pengulangan konsep.
Pembelajaran terprogram terdapat dua tipe yang bisa digunakan yaitu disebut "Linear programming dan Branching programming. Branching programming (Ensiklopedia Brintannica Online) adalah tipe pembelajaran terprogram yang memungkinkan masing-masing siswa untuk memahami konsep satu persatu secara benar untuk dapat melanjutkan ke konsep berikutnya. Jika pengetahuan awal salah satu siswa belum benar, maka hanya siswa itu saja yang akan dikembalikan pada bagian konsep belum dipahaminya secara benar dan jika siswa memiliki pengetahuan awal yang benar maka siswa dapat melanjutkan pada konsep-konsep berikutnya.

Kelebihan bahan ajar dengan branching program memberi kesempatan kepada mahasiswa melakukan pekerjaan proyek yang dapat dipilih atau dikembangkan untuk mencapai hasil pembelajaran tertentu. Tujuannya agar mahaiswa mampu mempunyai kemandirian dan keterampilan dalam menyelesaikan tugas yang dihadapinya.

Salah satu media pembelajaran yang dapat dikembangkan secara digital adalah media pembelajaran dengan branching program berbasis komputer dengan perangkat lunak nya berupa Macromdia flash. Macromedia Flash merupakan aplikasi yang diperuntukkan bagi pengguna profesional, yang dapat dengan mudah membuat demonstrasi interaktif serta simulasi dalam berbagai format, termasuk Flash (SWF) dan EXE.

Selain animasi Flash tersebut dibangun menjadi format *.exe (executable file) yang artinya dapat berjalan di komputer dengan sistem operasi Windows manapun walau di komputer tersebut tidak terpasang Flash player plug-in. Melihat dari media pembelajaran dengan branching program dan kemampuan Macromdia flash menciptakan media pembelajaran melalui aplikasi Flash yang memenuhi kriteria pemilihan media.

\section{PENDEKATAN PEMECAHAN MASALAH}

\section{Metode}

Penelitian ini adalah penelitian pengembangan (Research and Development), Dalam penelitian pengembangan ini produk yang dihasilkan berupa media pembelajaran menggunakan macromedia flash. Peneliti mengembangkan media pembelajaran dengan branching program berbasis komputer dengan materi mata kuliah Perancangan Sistim Digital. Model pengembangan yang dipilih dalam penelitian ini adalah model Instruksional Development Institute (IDI).

Model IDI menetapkan prinsip-prinsip pendekatan sistem yang meliputi tiga tahap yaitu define, develop, dan evaluate dengan analisis 
kebutuhan, analisis karakteristik mahasiswa dan analisis materi dikembangkan media pembelajaran dengan branching program berbasis komputer yang valid, praktis dan efektif [2]. Untuk menguatkan deskripsi data kuantitatif didapatkan dari hasil dokumentasi, media pembelajaran observasi kepada subjek penelitian

\section{Media Pembelajaran}

Media Pembelajaran merupakan gabungan dari dua kata yakni media dan pembelajaran. Media berasal dari bahasa latin dan merupakan bentuk jamak dari kata "medium" yang secara harfiah berarti perantara. Jadi media adalah perantara atau pengantar pesan dari pengirim kepada penerima pesan. Media berasal dari bahasa latin medius, yang secara harfia berarti 'tengah', 'perantara' atau 'pengantar', dalam bahasa arab media adalah perantara (waasaailah) atau pengantar pesan dari pengirim kepada penerima pesan [1]. Oleh karena itu secara bahasa media dapat dikatakan sebagai alat perantara atau pengatar suatu pesan dari pemberi pesan kepada penerima pesan. Alat tersebut dapat berbentuk perangkat keras (hardware) maupun perangkat lunak (software).

Penyampaian pesan ini bisa dilakukan melalui simbol-simbol komunikasi berupa simbolsimbol verbal dan non-verbal atau visual, yang selanjutnya ditafsirkan oleh penerima pesan. Dalam proses pembelajaran, media yang digunakan guru harus sesuai dengan tujuan pembelajaran yang telah ditetapkan sehingga mampu merangsang dan menumbuhkan minat siswa dalam belajar. Dengan demikian akan tumbuh interaksi antara media pembelajaran dan siswa dalam belajar. Adanya interaksi positif antara media pembelajaran dan siswa pada akhirnya akan mampu mempercepat proses pemahaman siswa terhadap isi pembelajaran.

Karakteristik siswa berhubungan dengan aspek-asek yang melekat pada diri siswa seperti motivasi, bakat, minat, kemampuan awal, gaya belajar, kepribadian dan lainnya. Karakteristik peserta didik yang amat kompleks tersebut harus juga dijadikan pijakan dasar dalam menentukan media pembelajaran yang akan digunakan. Tanpa mempertimbangkan karakteristik siswa tersebut. Maka penerapan media pembelajaran tertentu tidak bisa mencapai hasil belajar secara maksimal.

Hasil belajar dalam proses pembelajaran dipengaruhi oleh faktor metode dan media pembelajaran yang digunakan. Keduanya saling berkaitan, di mana pemilihan metode tertentu akan berpengaruh terhadap jenis media yang akan digunakan. Artinya bahwa harus ada kesesuaian di antara keduanya untuk mewujudkan tujuan pembelajaran. Ada hal-hal lain yang juga perlu diperhatikan dalam pemilihan media seperti: konteks pembelajaran, karakteristik siswa, dan respon diharapkan dari siswa.

Media pembelajaran dapat dikalsifikasikan sebagai media visual yaitu media yang hanya dapat dilihat dengan menggunakan indra penglihatan yang terdiri atas media yang dapat diproyeksikan dan media yang tidak dapat diproyeksikan yang biasanyan berupa gambar diam atau gambar bergerak, Media audio yaitu media yang mengandung pesan dalam bentuk auditif yang dapat merangsang pikiran, perasaan, perhatian, dan kemauan para peserta didik untuk mempelajari bahan ajar, media audio-visual (video) yaitu media yang merupakan kombinasi audio dan visual atau biasa disebut dengan media pandang-dengar. Media objek merupakan merupakan media tiga dimensi yang menyampaikan informasi tidak dalam bentuk penyajian, melainkan melalui ciri fisiknya sendiri, seperti ukurannya, bentuknya, beratnya, susunannya, warnanya, fungsinya, dan sebagainya.

Media ini dapat dibagi menjadi dua kelompok, yaitu media objek sebenarnya dan media objek pengganti. Media interaktif adalah media yang dapat mengahasilkan interaksi antara siswa dengan media, merupakan gabungan dari media tertulis, audio, visual, dan simulasi dari bentuk asli (nyata). Media pembelajaran berbasis komputer (ICT) merupakan media pembelajaran yang dibuat dan digunakan dengan berbantuan komputer. Dari keenam bentuk media pembelajaran di atas dapat dibuat dan digunakan dengan mengguanakan komputer. Media pembelajaran berbasis komputer ini seperti, Software Komputer, Mobile, Internet (Web, Media Sosial).

Media pembelajaran mempunyai manfaat yang sangat strategis dalam pembelajaran. Manfaat media pembelajaran secara umum jika disimpukan dari pendapat ketiga ahli di atas adalah untuk memperjelas penyajian pesan agar tidak terlalu bersifat verbalistik, mengatasi keterbatasan ruang, waktu, dan daya indera. Penggunaan media pendidikan secara tepat dan bervariasi dapat mengatasi sikap pasif anak didik, karena pembelajaran dengan menggunakan media dapat menimbulkan kegairahan belajar, memungkinkan interaksi lebih langsung antara anak didik dengan lingkungan dan kenyatan, dan memungkinkan anak didik belajar sendiri-sendiri menurut kemampuan dan minatnya.

Untuk pengembangan media pembelajaran diperlukan prosedur-prosedur tertentu yang sesuai dengan jenis kemampuan yang ingin dicapai, struktur isi bidang studi serta memenuhi kriteria umum yang berlaku bagi pengembangan produk- 
produk pembelajaran. Analisis kebutuhan dilakukan agar media yang dikembangkan betulbetul sesuai dengan kebutuhan. Jika membuat program media tentu saja berharap agar media tersebut digunakan atau dimanfaatkan dalam kegiatan pembelajaran. Program media tersebut hanya dimanfaatkan kalau memang dibutuhkan/ diperlukan siswa. Oleh karena itu, langkah pertama dalam pengembangan media adalah melakukan analisis kebutuhan.

Perumusan tujuan merupakan sesuatu yang sangat penting dalam pembelajaran. Tujuan dapat memberi arah kepada proses pembelajaran yang dilakukan dan tujuan pembelajaran dapat dijadikan acuan dalam mengukur apakah tindakan kita betul atau salah. Dalam pengembangan media pembelajaran, tujuan harus dijadikan pijakan dalam proses pengembangan. Media yang dikembangkan harus sesuai dengan tujuan pembelajaran yang telah dirumuskan. Dari tujuan yang telah ditetapkan, kegiatan selanjutnya adalah mengembangkan/ merumuskan butir-butir materi pembelajaran.

Materi pembelajaran harus terkait dengan tujuan, dan setelah materi dirumuskan baru dibuat alat untuk mengukur keberhasilan belajar. Tahap selanjutnya adalah mengembangkan atau melakukan penulisan naskah media pembelajaran. Untuk melihat validitas media pembelajaran harus dilakukan uji coba. Jika dalam tahap uji coba ternyata media yang telah dikembangkan masih ada kekurangan maka harus dilakukan revisi. Jika media pembelajaran sudah dianggap baik, baru dilakukan proses produksi media. Media pembelajaran didesain dengan warna dan tampilan yang menarik agar dapat menarik perhatian dan interaksi dari siswa sebagai pengguna media tanpa mengabaikan kebenaran materi pembelajaran yang akan diajarkan.

\section{Branching Program}

Alternatif pendekatan pembelajaran pada mata kuliah Perancangan Sistem Digital untuk membantu pemahaman mahasiswa adalah bahan ajar dengan terprogram. Pembelajaran terprogram atau programmed learning seperti dikemukakan berdasarkan teori B.F Skinner pada tahun 1950 adalah: "Educational tecnique characterized bysefpaced, self-administered instruction presented in logical sequence and with much repetition of concepts".

Pembelajaran terprogram menghadirkan instruksi pembelajaran dalam urutan logis dan banyak pengulangan konsep. Pada pembelajaran terprogram terdapat dua tipe yang bisa digunakan yaitu disebut "Linear programming dan Branching programming.
Branching programming (Ensiklopedia Brintannica Online) adalah tipe pembelajaran terprogram yang memungkinkan masing-masing siswa untuk memahami konsep satu persatu secara benar untuk dapat melanjutkan ke konsep berikutnya. Jika pengetahuan awal salah satu siswa belum benar, maka hanya siswa itu saja yang akan dikembalikan pada bagian konsep belum dipahaminya secara benar dan jika siswa memiliki pengetahuan awal yang benar maka siswa dapat melanjutkan pada konsep-konsep berikutnya.

Kelebihan media pembelajaran dengan branching program memberi kesempatan kepada mahasiswa melakukan pekerjaan proyek yang dapat dipilih atau dikembangkan untuk mencapai hasil pembelajaran tertentu. Tujuannya agar mahaiswa mampu mempunyai kemandirian dan keterampilan dalam menyelesaikan tugas yang dihadapinya. Dalam materi gerbang logika, terdapat berbagai indikator dan tujuan belajar yang kompleks dan sulit diamati hanya dengan mengandalkan hasil akhir dari kegiatan praktikum maupun tes tulis saja. Oleh karena itu agar hasil pembelajaran dapat membandingkan kinerja kemandirian mahasiswa serta dapat meningkatkan kompetensi mahasiswa.

\section{Matakuliah Perancangan Sistem Digital}

Mata kuliah Perancangan Sistem Digital merupakan mata kuliah teori yang terdiri dari 2 Satuan Kredit Semester (SKS) yang diberikan kepada mahasiswa pada semester empat. Tujuan mata kuliah perancangan sistem digital diberikan kepada mahasiswa untuk mendukung dan memberikan pembelajaran teori untuk yang akan membimbing mahasiswa dalam perancangan proyek akhir sehingga diperlukan pemahaman dan keterampilan yang baik terhadap konsep gerbang logika, memory, squensial, perancangan logika urutan dalam bentuk sinkron dan perancangan logika urutan dalam bentuk tak sinkron.

Mata kuliah perancangan sistem digital diterapkan pada semester empat dan hanya keluar pada semester genap. Bagi mahasiswa yang gagal akan mengulang pada tahun-tahun berikutnya pada semester empat. Bagi mahasiswa yang gagal dan untuk mengulang mata kuliah Perancangan Sistem Digital maka harus melapor ke kantor Jurusan Teknik Elektronika karena matakuliah tersebut sudah dipaketkan kepada mahasiswa baru untuk angkatan mahasiswa baru berikutnya.

Mata kuliah ini juga menjadi dasar untuk mengambil mata kuliah keahlian atau mata kuliah konsentrasi bagi mahasiswa Program Studi Teknik Elektronika (D3). 
Struktur bidang studi mata kuliah yang satu dengan yang lainnya tentu berbeda dengan struktur kuliah lainnya. Perbedaan bidang studi tersebut membutukan media pembelajaran yang berbeda pula. Itulah sebabnya seorang pendidik terhadap struktur studi yang di ajarkannya sangat penting dalam penetapan metode pembelajaran yang akan digunakan. Penelitian ini akan mengembangkan media pembelajaran pada mata kuliah Perancangan Sistem Digital, dari struktur kurikulum berbasis kompetensi terkait KKNI tahun 2015 Program Studi Teknik Elektronika (D3) dengan Materi Mata Kuliah Perancangan Sistem Digital.

Mata kuliah Perancangan Sistem Digital membutuhkan bahan ajar yang mampu memberikan stimulus dan respon kepada mahasiswa karena sifat mata kuliah ini pemahaman dan penerapan, salah satu cara dapat ditempuh oleh dosen yaitu dengan memberi visualisasi terhadap materi yang dianggap membutuhkan penjelasan lebih dari sekedar kata-kata saja. Hal ini sangat diperlukan agar mahasiswa tidak hanya membayangkan apa yang dijelaskan oleh dosen, namun dapat merasakan sendiri pengalaman belajar yang lebih nyata dan maksimal.

Berdasarkan kurikulum yang dipakai dalam proses pembelajaran di Program Studi Teknik Elektronika (D3) diperoleh materi yang akan dikembangkan dalam media pembelajaran dengan branching program berbasis komputer yakni, Register, Rangkaian aritmatika serta Konversi $\mathrm{ADC}$ dan DAC. Penggunaan media pembelajaran dengan branching program membuat mahasiswa lebih mudah menguasai materi yang disajikan karena materi tersebut bisa dilihat secara berulangulang oleh mahasiswa. Media pembelajaran dengan branching program ini pada mata kuliah Perancangan Sistem Digital dirancang untuk bisa digunakan secara mandiri oleh mahasiswa.

\section{HASIL DAN PEMBAHASAN}

Media pembelajaran dengan branching program pada mata kuliah Peracangan Sistem Digital dikembangkan dengan menggunakan model pengembangan IDI, terdiri dari tahap pendefinisian (define) pengembangan (develop) dan evaluasi (evaluate). Dengan harapan setelah dilakukan pengembangan ini, maka akan didapatkan media pembelajaran dengan branching program yang valid, praktis, dan efektif untuk mata kuliah Peracangan Sistem Digital. Dalam proses pengembangan perlu dilakukan validasi, uji praktikalitas dan uji efektifitas.

Tujuan dari validasi oleh ahli adalah untuk memperoleh masukan, kritik, dan saran perbaikan untuk kesempurnaan media yang dikembangkan. Data uji validasi diperoleh melalui instrumen validasi yang diisi oleh beberapa orang validator yang merupakan ahli media pembelajaran.

Validasi ahli media difokuskan pada tampilan atau penyajian yang dilihat dari sudut pandang media. Validasi oleh ahli media bertujuan agar produk bahan ajar dengan branching program berbasis komputer yang dikembangkan menjadi produk yang berkualitas secara aspek pemograman dan tampilan.

Data dari validator di peroleh dari angket yang telah diberikan penilaian oleh dua orang validator. Berdasarkan hasil analisis validitas yang dilihat dari aspek media dan bahasa didapatkan ratarata validasi desain yaitu $91,66 \%$ dengan kategori sangat valid, dapat diambil rata-rata keseluruhan validasi media pembelajaran dengan branching program yaitu 91,66\% sehingga dapat disimpulkan media pembelajaran dengan branching program berbasis komputer tersebut termasuk pada kategori "sangat valid".

Saran dan penilaian dari validator dijadikan sebagai acuan untuk melakukan revisi terhadap bahan ajar berdasarkan hasil analisis validitas dan revisi terhadap media pembelajaran ini, kemudian didukung oleh hasil penelitian-penelitian yang telah dilakukan sebelumnya maka bahan ajar dengan branching program pada mata kuliah Perancangan Sistim Digita ini layak untuk diujicoba di lapangan.

Data kepraktisan media dengan branching program berbasis komputer diambil melalui hasil pengisian angket kepraktisan yang dilaksanakan di Program Studi D3 Teknik Elektronika yang bertujuan untuk melihat keterlaksanaan pembelajaran dengan menggunakan media pembelajaran dengan branching program ini. Untuk melihat kepraktisan, media pembeajaran dengan branching program yang valid kemudian digunakan oleh dosen dan mahasiswa sebagai media dalam proses pembelajaran. Di akhir pembelajaran, dosen dan mahasiswa diminta mengisi angket kepraktisan dari media yang telah digunakan.

Penilaian terhadap kepraktisan media pembelajaran ini diperoleh dari angket yang diisi oleh dosen/praktisi dan hasil penilaian yang diperoleh dari angket respon dosen terhadap praktikalitas media pembelajaran interaktif tercantum pada tabel 2 .

Tabel 2. Penilaian terhadap kepraktisan media dengan branching program berbasis 


\section{komputer}

\begin{tabular}{lcc}
\hline \multicolumn{1}{c}{ Praktisi } & $\%$ & $\begin{array}{c}\text { Level } \\
\text { Kategori }\end{array}$ \\
\hline Respon Dosen & $90,83 \%$ & Sangat Praktis \\
\hline Respon & $89,78 \%$ & Sangat Praktis \\
Mahasiswa & & \\
\hline
\end{tabular}

Sehingga dapat disimpulkan bahwa media pembelajaran dengan branching program yang dikembangkan sangat praktis digunakan oleh dosen dan mahasiswa pada proses pembelajaran Perancangan Sistim Digital Program Studi D3 Teknik. Hasil analisis praktikalitas media pembelajaran ini sejalan dengan hasil penelitian terdahulu yang dilakukan oleh Luki (2014) dalam penelitian menunjukkan bahwa bahan ajar yang dikembangkan memiliki tingkat kepraktisan oleh guru sebesar 93,45\% (sangat praktis) dan tingkat kepraktisan oleh siswa sebesar $89,90 \%$ (sangat praktis).

Hasil penelitian ini didukung dengan pendapat Arsyad (2010:56) menyatakan bahwa salah satu kelebihan branching program dengan media pembelaran interaktif adalah praktis penggunaannya dalam proses pembelajaran baik media yang digunakan oleh guru maupun media pembelajaran interaktif yang digunakan oleh siswa.

Keefektifan media pembelajaran dengan branching program ini dilakukan dengan cara membandingkan hasil belajar kelas eksperimen dengan kelas kontrol menggunakan hasil Uji Independent Sample T-Test yang tercantum pada Tabel 3.

Tabel 3. Uji Independent Sample T-test

Independent Samples Test

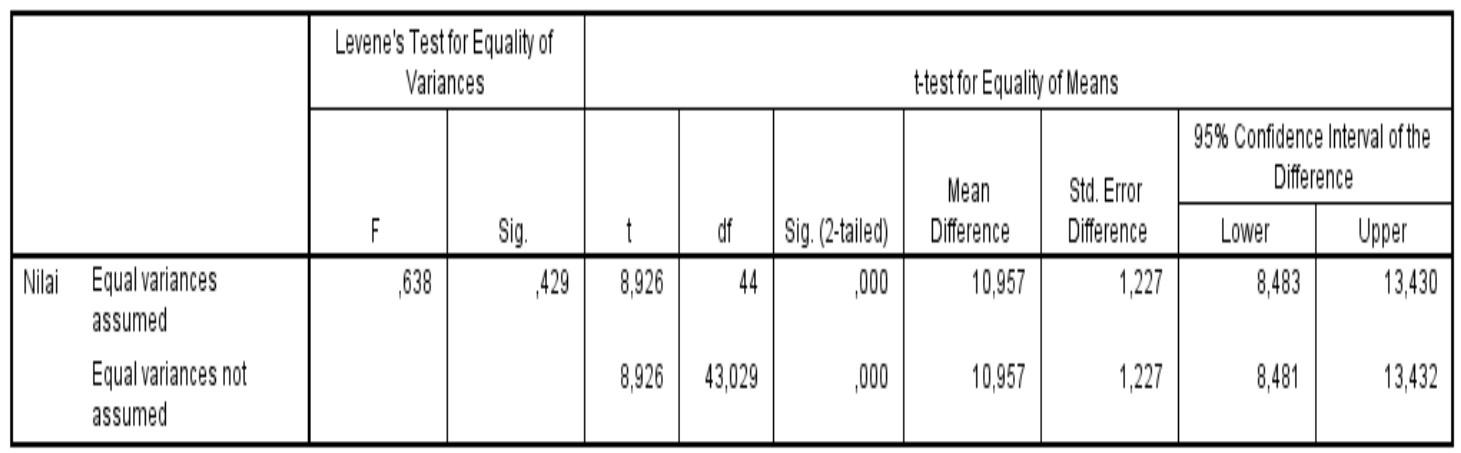

Berdasarkan tabel 3 diperoleh nilai Sig.(2tailed) sebesar $0,000<0,05$ sesuai dasar pengambilan keputusan dalam Uji Independent Sample T-Test dapat disimpulkan Ho ditolak dan Ha diterima yang artinya bahwa terdapat pengaruh yang signifikan antara rata-rata kelas eksperimen dan kelas kontrol dalam pengembangan media pembelajaran dengan branching program berbasis komputer pada mata kuliah perancangan sistem digital di program studi D3 teknik.

Berdasarkan hasil analisis tersebut media pembelajaran dengan branching program berbasis komputer efektif digunakan pada mata kuliah Perancangan Sistim Digital Program Studi D3 Teknik.

Hasil analisis terhadap efektifitas media pembelajaran dengan branching program ini sejalan dengan hasil penelitian terdahulu yang dilakukan oleh Luki (2014) dalam penelitiannya menunjukan bahwa media pembelajaran yang dikembangkan efektif digunakan pada proses pembelajaran Rangkaian Listrik di lihat dari perbedaaan hasil belajar siswa antara sebelum dan sesudah menggunakan media pembelajaran yang dikembangkannya Selain itu hasil penelitian tersebut didukung dengan pendapat yang dikemukakan oleh Arsyad (2010:58) yang menyatakan bahwa media pembelajaran interaktif dapat meningkatkan aktifitas belajar siswa dalam proses pembelajaran yang pada akhirnya dapat meningkatkan hasil belajar siswa.

Hasil penelitian menunjukkan bahwa media pembelajaran dengan branching program yang dikembangkan merupakan media pembelajaran yang valid, praktis dan efektif digunakan pada proses pembelajaran Perancangan Sistim Digital Program Studi D3 Teknik. Hasil penelitian ini didukung oleh teori dan penelitian terdahulu yang telah dialakukan oleh peneliti lain seperti yang telah dibahas sebelumnya. Dengan demikian media pembelajaran dengan branching program berbasis komputer ini dapat dijadikan sebagai alternatif pilihan media pembelajaran yang akan digunakan dalam proses pembelajaran Perancangan Sistim 
Digital.

\section{KESIMPULAN}

1. Pengembangan media pembelajaran dengan branching program berbasis komputer sesuai digunakan pada mata kuliah Perancangan Sistem Digital di Program Studi D3 Teknik, isi media pembelajaran dengan branching program yang dihasilkan pada penelitian ini berupa file yang di dalamnya berisi mata kuliah Perancangan Sistem Digital. Proses pengembangan media pembelajaran interaktif ini mengacu pada model pengembangan IDI (Instruction develop Institute) yaitu Tahap define, Tahap develop dan Tahap evaluate.

2. Validitas media pembelajaran dengan branching program berbasis komputer pada mata kuliah Perancangan Sistem Digital di Program Studi D3 Teknik divalidasi oleh 4 orang validator, 2 orang untuk validasi media dan 2 orang untuk validasi materi. Hasil penilaian untuk validasi media dinyatakan sangat valid dan hasil penilaian untuk validasi materi juga dinyatakan sangat valid oleh validator.

3. Praktikalitas media pembelajaran dengan branching program berbasis komputer pada mata kuliah Perancangan Sistem Digital di Program Studi D3 Teknik dilakukan pada dosen mata kuliah Perancangan Sistem Digital dan 23 orang mahasiswa. Hasil penilaian dosen dan mahasiswa terhadap praktikalitas media pembelajaran dengan branching program berbasis komputer ini dinyatakan bahwa media pembelajaran dengan branching program berbasis komputer ini berada pada kategori sangat praktis.

4. Efektivitas media pembelajaran dengan branching program berbasis komputer pada mata kuliah Perancangan Sistem Digital di Program Studi D3 Teknik melalui tes hasil belajar siswa yaitu berupa kelas eksperimen dan kelas kontrol. Hasil uji efektivitas dengan branching program berbasis komputer menyatakan bahwa media pembelajaran ini dalam kategori efektif.

\section{DAFTAR PUSTAKA}

[1] Arsyad, Azhar. Media Pembelajaran. Jakarta: Raja Grafindo Persada. 2010

[2] Grabowski, BL. Generative Learning Contribution to The Design of Instruction and Learning. Pen State University. 2003.

[3] Made Wena. Strategi Pembelajaran Inovatif Kontemporer. Jakarta: Bumi Aksara. 2014.

[4] Owen, Robert S\& Bosede Aworuwa. Prorammed Instruction, Programmed Branching and Learning Outcomes (hlm.2596). USA:IGI Global. 2008. 